DOI https://doi.org/10.30525/978-9934-588-81-5-2.20

\title{
РЕОЛОГІЧНІ ТА ТЕХНОЛОГІЧНІ ОСОБЛИВОСТІ ВИГОТОВЛЕННЯ ШАМПУНЮ ДЛЯ ЛІКУВАННЯ СЕБОРЕЙНОГО ДЕРМАТИТУ
}

\author{
Заїка C. B. \\ асистент кафедри товарознавства \\ Начіональний фармачевтичний університет \\ Баранова I. I. \\ доктор фармачевтичних наук, професор, \\ завідувач кафедри товарознавства \\ Начіональний фармачевтичний університет \\ Безпала Ю. О. \\ кандидат фармацевтичних наук, \\ асистент кафедри товарознавства \\ Національний фармацевтичний університет \\ Мартинюк Т. В. \\ кандидат фармачевтичних наук, \\ дочент кафедри косметології та аромології \\ Начіональний фармачевтичний університет \\ м. Харків, Україна
}

Одним 3 наукових напрямків кафедри товарознавства $є$ розробка сучасних піномийних засобів [1]. При вивченні ринку та споживчого попиту з даного напрямку, нами було відмічено, що актуальним $\epsilon$ розробка піномийних засобів для профілактики та лікування себорейного дерматиту (СД). Це пов'язано, з тим, що СД відноситься до найбільш поширених дерматологічних захворювань у світі [2]. Для лікування найчастіше використовують засоби, що містять глюкокортикостероїди, антимікробні та протигрибкові речовини (наприклад, пиритіон цинку, дьоготь, саліцилову кислоту, сірку тощо) [3]. Однак застосування більшості з них дає короткочасний ефект, тому пошук нових підходів до лікування СД залишається актуальним завданням. Тому, найчастіше використовують саме спеціальні піномийні засоби - шампуні, які містять у своєму складі комплекс поверхнево-активних речовин (ПАР) та активні фармацевтичні інгредієнти (АФІ), за рахунок яких і відбувається процес лікування даної патології. Завдяки проведеним комплексним дослідженням (фармакотехнологічним, структурно-механічним, мікробіологічним тощо) було обрано комплекс АФІ ( $\alpha$-ліпоева кислота, октопірокс, гідроксілсечовина) і допоміжних ре86 
човин (детергенти, зволожувачі, консерванти тощо), обгрунтовано раціональний склад піномийної основи та шампуню $[4,5]$. Головним напрямком нашого дослідження стало вивчення реологічних аспектів та розробка технології шампуню для лікування СД.

Структурно-механічні властивості визначали за допомогою віскозиметра Brookfield DV-II + PRO (США) з ротаційним адаптером із системою коаксіальних циліндрів [6, с. 63]. 3 метою вивчення типу течії та визначення тиксотропних властивостей нами були побудовані реограми досліджуваних піномийних основ з АФІ: основа $+0,5 \% \alpha$-ліпоєвої кислоти, основа $+0,5 \%$ октопіроксу; основа $+5,0 \%$ гідроксілсечовини, а також зразок готового шампуню. Дані реограми показують залежність напруги зсуву $(\tau$, Па) від градієнта швидкості (Dr, c-1) (pис. 1).

Дані реопараметрів отримували методом безперервного всезростаючого руйнування структури, як функції напруги зсуву. Визначення були проведені при збільшенні числа обертів шпинделя 320 до 100 об/хв, досягаючи постійної напруги зсуву при максимальному числі обертів і подальшого зменшення числа обертів шпинделя [6, с. 91].

Як видно з рис. 1, усі зразки мали псевдопластичний тип течії з незначними тиксотропними властивостями, що пов'язано з відсутністю гелеутворювачів та емульгаторів у складі (при розробці використовували електролітний тип загущення за допомогою натрію хлориду). Із рис.1. видно, що найкращі в'язкостні характеристики мали зразки с додаванням октопірокса, гідроксілсечовиною і сама піномийна основа, найменші - $3 \alpha$-ліпоєвою кислотою. Дослідження залежності структурної в'язкості від градієнта швидкості зсуву усіх розроблених зразків показало, що структурна поступово зменшувалася з збільшенням градієнта швидкості зсуву (рис. 2), але особливо інтенсивно структурна в'язкість зменшується в діапазоні збільшення деформації від 20 до 34 с-1. Далі структурна в'язкість змінюється не так інтенсивно і при швидкості деформації від 60 с-1 описується прямолінійною залежністю.

Встановлені залежності величини структурної в'язкості від швидкості зсуву свідчать про більш легкий і рівномірний розподіл піномийного засобу на поверхні шкіри дитини. Введення активних компонентів вплинуло на значення структурної в'язкості, однак на характер зменьшення в'язкості (форму кривих) від градієнта швидкості зсуву відбулося незначно.

Таким чином, виходячи з реологічних властивостей зразків, раціональним буде поступове введення АФІ у розроблену піномийну основу наступним образом: октопірокс, гідроксілсечовина, $\alpha$-ліпоєва кислота. 


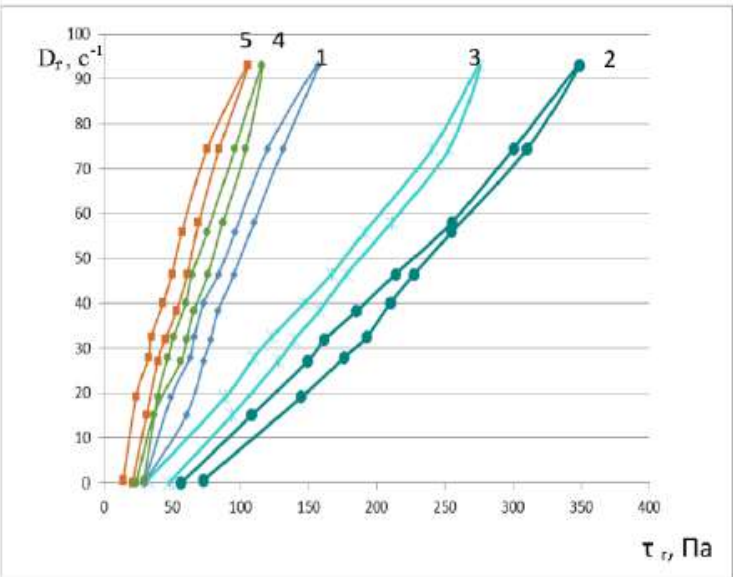

Рис. 1. Реограми піномийних основ: 1 - піномийна основа, 2 - основа $з$ октопіроксом, 3 - основа 3 гідроксілсечовиною, 4 - готова рецептура, 5 - основа $3 \alpha$-ліпосвою кислотою

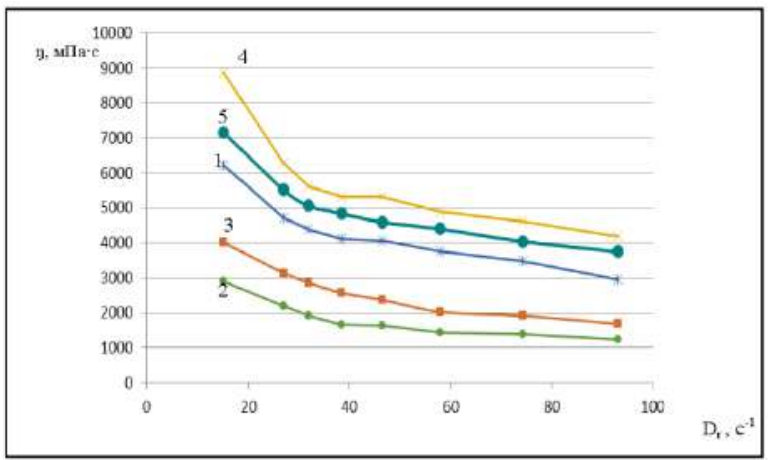

Рис. 2. Залежність структурної в'язкості піномийних зразків від швидкості зсуву: 1 - піномийна основа, 2 - основа $3 \alpha$-ліпоєвою кислотою, 3 - готова рецептура, 4 - основа 3 октопіроксом, 5 - основа 3 гідроксілсечовиною

Технологічний процес починався з приготування піномийної основи за наступною схемою: у частині води очищеної розчиняли послідовно ПАР аніонного характеру (при температурі $70-80^{\circ} \mathrm{C}$, перемішували протягом 60 хв, швидкість мішалки 40 об/хв). Окремо готували 
суспензійний розчин октопіроксу. Після повного розчинення аніонних ПАР додавали отриманий розчин із октопіроксом та розчиняли його при тих же умов. Потім у отриманий прозорий розчин вводили амфотерні та неіоногенні детергенти (при температурі $40-45^{\circ} \mathrm{C}$, перемішували протягом 20 хв, швидкість мішалки 40 об / хв). Паралельно готували розчині із $\alpha$-ліпоєвої кислоти (необхідну кількість кислоти розчиняли у водному розчині трометамола). Після при температурі 25 $30^{\circ} \mathrm{C}$ послідовно вводили до реактору гідроксілсечовину та розчин $\alpha$-ліпоєвої кислоти та обрану комбінацію консервантів (ніпагін та феноксіетанол). Компоненти гомогенізували за допомогою якірної мішалки протягом 35 хв до отримання однорідного прозорого розчину жовтуватого кольору із характерним запахом сировини.

Отриманий піномийний розчин залишали у відстійнику до повного охолодження, а після чого додавали необхідну кількість натрію хлориду, який вводився порційно при постійному перемішуванні та під суворим наглядом технолога. У результаті була отримана однорідна, прозора, жовтого кольору гелева маса.

3 метою перевірки необхідних фізико-хімічних показників якості, а саме знаення рівня рН відбирали зразки маси 3 двох місць реактора (верх і низ), по 50 мл. Після отримання результатів лабораторного дослідження зразків, рівень $\mathrm{pH}$ корегували за допомогою молочної кислоти. Молочну кислоту вводять в необхідній кількості безпосередньо у реактор i розмішували за допомогою рамної мішалки (35-40 об/хв) протягом 5-7 хв. Додатково відбирають зразки для повторної перевірки значення $\mathrm{pH}$. Отриманий засіб залишали для відстоювання протягом 24 годин. Після його передавали на розфасовку у обрану первинну тару, а саме ПЕТ-флакони по 250 мл із дозатором.

Вивчено вплив обраних АФІ ( $\alpha$-ліпоєва кислота, октопірокс, гідроксілсечовина) на структурно-механічні властивості розробленої піномийної основи. Виходячи 3 проведених реологічних досліджень обгрунтована послідовність введення активних фармацевтичних інгредієнтів. В результаті проведених технологічних досліджень визначено умови приготування, послідовність змішування, а також температурний режим кожної стадії шампуню.

\section{Література:}

1. Borda J.L., Wikramanayake T. C. Seborrheic Dermatitis and Dandruff: A Comprehensive Review. Journal of Clin. Investig. Dermatol. 2015. № 3 (2). P. 123-131.

2. Goldenberg G. Optimizing treatment approaches in seborrheic dermatitis. Journal of Clin Aesthet Dermatol. 2013. № 6:2. P. 44-49. 
3. Zaika S. V., Bezpala Yu. O., Shmelkova K. S., Shmatenko O. P. The study of the assorment of dermatological products for the local treatment of seborrheic dermatitis. Social'na farmaciâ $v$ ohoroni zdorov'â. 2018. № 4 (3). P. 69-79.

4. Baranova I., Zaika S., Bezpala Yu., Roik O., Zaporozhska S., Shostak L. Development of foaming shampoo base for the treatment of Seborrheic Dermatitis. Journal of Advanced Pharmacy Education \& Research. 2020. Vol 10, № 1. P. 143-149.

5. Заїка С. В., Баранова І. І., Безпала Ю. О., Мартинюк Т. В. Обгрунтування складу піномийного засобу за допомогою методу мікрофотографування. Фармацевтичний часопис. 2020. № 1 (53). С. 28-34.

6. Жук О. В. Розробка складу та технології дитячого піномийного засобу: дис. ... канд. фармац. наук: 15.00.01. Харків, 2015. 140 с.

DOI https://doi.org/10.30525/978-9934-588-81-5-2.21

\title{
ВИВЧЕННЯ АНТИОКСИДАНТНОЇ АКТИВНОСТІ ПОЛІФЕНОЛЬНОГО ЕКСТРАКТУ 3 ЛИСТЯ ЖУРАВЛИНИ
}

\author{
Кравченко Г. Б. \\ кандидат біологічних наук, \\ завідувачка кафедри біологічної хімії \\ Національний фармачевтичний університет \\ Красільнікова О. А. \\ кандидат біологічних наук, \\ доиент кафедри біологічної хімії \\ Національний фармацевтичний університет \\ м. Харків, України
}

Актуальним питанням сучасної фармації є пошук, розробка та дослідження рослинної сировини 3 метою створення нових препаратів. На цей час особливу увагу привертають представники родини Вересових, оскільки вони $€$ джерелом біологічно активних сполук з широким спектром властивостей [1]. Одним з представників родини Вересових $\epsilon$ журавлина. В Україні найпоширенішим видом $є$ журавлина звичайна, яка має господарське значення. Хімічний склад плодів журавлини добре вивчений [2]. Проте встановлено, що в листі журавлини у порівнянні з плодами міститься значно менше цукрів, проте у 10 разів більше поліфенольних сполук [3]. Проте, на відміну від плодів біологічна активність сполук з листя журавлини ще практично не вивчена. На кафедрі фармакогнозії Національного фармацевтичного універси90 